\title{
The Principle of Inherent Complication of the English Predicate
}

\author{
Rauza I. Kuriaeva* \\ Kazan National Research Technological University \\ 68 Karl Marx Str., Kazan, 420015, Russia
}

Received 18.07.2015, received in revised form 17.09.2015, accepted 06.10.2015

There is a great variety of textbooks on the English language. The consecution of teaching English in them is different. Students often learn English without understanding it. The basis of any language is its grammar. The basis of English grammar is a predicate. Analysis of the English predicate structure allowed to reveal its inherent logicality that has a character of a law. The logicality is described with the help of a table and equations. The optimum consecution of the English predicate teaching is given in the form of a scheme. This logicality became a basis for working out an optimum consecution of teaching English that makes the process of studying English intelligible and consequently much easier and shorter.

Keywords: the English language, English grammar, the English predicate, the tense-aspectual forms of the English verb.

DOI: 10.17516/1997-1370-2015-8-11-2499-2504.

Research area: pedagogy, philology.

\section{Introduction}

When studying the English language mastering of English grammar presents the greatest difficulties. My practical experience of being a professional translator of English scientific and technical texts has allowed me to come to the conclusion that in the English sentence the predominant role is played by a predicate.

In English grammar it is a predicate that has the most complicated forms. It may consist of from one to four parts (verbs and participles), so the English verb tense-aspectual forms present the most difficult part of English grammar. For learning some complicated things (in our case it is the English verb tense-aspectual forms) a person must understand them. We understand much better if we go from easy things to more and more complicated things in a logical way.

There is a great variety of textbooks on the English language. Each author offers his own way of the English language teaching and in particular of the English verb tense-aspectual forms. But in all the analysed textbooks the way of teaching is based on the frequency of usage of a grammar phenomenon but not on the level of its complication. Usually the authors first examine the most frequently used tense-aspectual forms and then those that are used more and more seldom. And the authors don't pay attention to the fact that the more frequently used tenseaspectual forms are complicated and based on those forms that are used more seldom but are

(C) Siberian Federal University. All rights reserved

* Corresponding author E-mail address: rauza-k@rambler.ru 
simpler. As a result students have to memorize incomprehensible complicated tense-aspectual forms without understanding how they are built. Their knowledge stays at a low level and the progress is very slow.

For example, in one of the best, to my mind, English textbooks by E. V. Sinyavskaya \& others first the verbs to be and to have are studied, then the Indefinite Active and Passive Tenses, then Continuous Active and Passive Tenses, then the Perfect Active and Passive Tenses and only after that Participle I and Participle II are studied with the help of which the previous tense-aspectual forms (except the Indefinite Active) are formed.

Foreign textbooks have the same drawbacks. For example, in the widespread study book for elementary students of English by R. Murphy he begins with the verb to be, then he explains the Present Continuous, the Present and Past Simple, the Past Continuous, the Present Perfect, the Indefinite Passive, and then the verbs to be, to have and to do in the Present and Past Simple.

In the most commonly used basic English textbook by N. A. Bonk \& others the tense-aspectual forms are studied in the following sequence: the verb to be, Participle I, the Present Continuous Active Tense, the Present Indefinite Active Tense, then to be going to, the Past Indefinite Active Tense, the verb to have and expression to have got, Participle II and the Present Perfect Active Tense, the Future Indefinite Active Tense, the Future Indefinite Active in the Past Tense u the Past Perfect Tense. Then they study the Present, Past, Future Indefinite Passive Tenses and the Present Perfect Passive Tense. After that-the Past and Future Continuous Active Tenses. Then they study Participle I and Participle II in the functions of an attribute and an adverb, Gerund, the Past and Future Perfect Active Tenses, the Present, Past Continuous Passive and Perfect Continuous Active Tenses.

Here we see the same drawback: first they study the more frequently used English verb tense-aspectual forms and then those that are used more seldom. Besides, in that textbook special cases of tense-aspectual forms are studied earlier than the tense-aspectual form itself and vice versa, a special case is studied much later than the main tense-aspectual form. That makes English grammar difficult to learn. For example:

a) after studying the more complicated form the Present Continuous Active Tense they study the simpler form the Present Indefinite Active Tense, and only after that they study the expression to be going to which is the special case of the Present Continuous Active Tense which they studied much earlier;

b) they study simultaneously the verb to have and the expression to have got which is a special case of the Present Perfect Active Tense that is studied much later;

c) Participle $I$ and Participle $I I$ are components of almost all the English verb tense-aspectual forms but they themselves are studied the last. That means that a component of a construction is studied later than the whole construction itself.

As a result students have to memorize the things which they don't understand.

\section{Theoretical framework}

First let's consider the gradual process of complicating of the English verb: 1) A verb has a form of the infinitive, which can be used in the sentence with or without a particle to. 2) A verb has an ending $-s$ in the Present Tense. 3) A verb may have an ending - ed if it is in the Past Tense and if it is a regular verb. 4) A verb has an ending -ing in the form of Participle I. 5) And the verb has its so-called third form if it is in the form of Participle II.

Almost all kinds of a predicate are presented in the table taken from the «Textbook on the English language» by Bonk \& others [V. 2, p. 572-573]. We have added to the table a line with 
formulas of a structure of each tense-aspectual form of a verb (see the Table).

This line shows, that the Continuous Active is a combination of the verb to be with Participle I of a notional verb; the Perfect Active is a combination of the verb to have with Participle II of a notional verb; the Perfect Continuous is a combination of the verb to have + been + Participle I of a notional verb; Indefinite Passive is a combination of the verb to be with Participle II of a notional verb; the Continuous Passive is a combination of the verb to be + being + Participle II of a notional verb; the Perfect Passive is a combination of the verb to have + been + Participle II of a notional verb. But the forms being and been are Participle I and Participle II of the verb to be. This means, that complex forms of an English predicate consist of a combination of the verbs to be and to have with Participle I and II, and Participle I and II are formed both from notional verbs, and from the auxiliary verb to be. Only in the Present and Past Indefinite Active Tenses a predicate consists of one verb to be or to have or any verb of action, except for their combination with modal verbs. In the Future Indefinite Active Tense a predicate consists of two verbs: auxiliary verbs shall and will in combination with a notional verb.

We can see that tense-aspectual forms of a verb may consist of:

1) the verb to be;
2) the verb to have;

3) Participle I which has an ending -ing,

4) Participle II.

\section{Logicality of the English verb tense-aspectual forms}

The complication of the formulas given in a separate line of the table of the English verb tense-aspectual forms (see the Table) we can show in the following way:

to be + Participle I-the Continuous Active

to be + Participle II - the Indefinite Passive

to be + being (Participle I) + Participle II the Continuous Passive

to have + Participle II - the Perfect Active

to have + been (Participle II) + Participle I the Perfect Continuous Active

to have+ been (Participle II) + Participle II the Perfect Passive.

These formulas show how the complicated tense-aspectual forms are generated from simpler elements. These formulas reveal the principle of complication of the English predicate: first the verb to be is combined with the Participle I, then with the Participle II, and then with both Participles simultaneously. Then we see combinations with the verb to have. First it is combined with the Participle II, then it is combined with the Participle II and the Participle I simultaneously,

Table. The table of the English verb Tense-aspectual forms

\begin{tabular}{|c|c|c|c|c|c|c|c|}
\hline \multicolumn{5}{|c|}{ Active } & \multicolumn{3}{|c|}{ Passive } \\
\hline & Indefinite & Continuous & Perfect & $\begin{array}{c}\text { Perfect } \\
\text { Continuous }\end{array}$ & Indefinite & Continuous & Perfect \\
\hline $\begin{array}{l}\text { The ad-ded line } \\
\text { with the formulas }\end{array}$ & & $\begin{array}{c}\text { to be }+ \\
\text { Partciple I }\end{array}$ & $\begin{array}{c}\text { to have }+ \\
\text { Participle II }\end{array}$ & $\begin{array}{c}\text { to have }+ \\
\text { been }+ \\
\text { Participle II }\end{array}$ & $\begin{array}{c}\text { to be }+ \\
\text { Participle II }\end{array}$ & $\begin{array}{c}\text { to be }+ \\
\text { being }+ \\
\text { Participle II }\end{array}$ & $\begin{array}{c}\text { to have }+ \\
\text { been }+ \\
\text { Participle II }\end{array}$ \\
\hline Present & 1 & 5 & 9 & 13 & 17 & 21 & 25 \\
\hline Past & 2 & 6 & 10 & 14 & 18 & 22 & 26 \\
\hline Future & 3 & 7 & 11 & 15 & 19 & 23 & 27 \\
\hline Future in the Past & 4 & 8 & 12 & 16 & 20 & 24 & 28 \\
\hline
\end{tabular}


and the last variant - combination of the verb to have with two Participles II.

It is in the system of tense-aspectual forms of the English verb of action that the logicality of English grammar reveals itself. Clearly defined mathematical features of English grammar made me think that the first computers could be invented only by Englishmen. Several years later I found out that the first calculating machines were really invented in England in the XVI-th century and one of the first programmers was John Byron's daughter Ada.

Looking at the formulas we can see that the verb to be appears most frequently in them. The verb to have is on the second place in frequency of occurrence. So in order to translate correctly most of tense-aspectual forms of the English verb of action first of all we must know well the verbs to be and to have. It means that we must begin studying English with these verbs - to be and to have.

If we take the predicate as the basis of English grammar, according to its gradual complication we can set out an accurate system of the grammatical structure of the English language (see the Fig.): the verb to be; the verb to have; then there is an infinitive of a notional verb with the particle $\boldsymbol{t o}$, that infinitive may be combined with the equivalents of modal verbs $\boldsymbol{t} \boldsymbol{t}$ be to, to be able to, to have to, the modal verb ought to; then there is an infinitive of a notional verb without the particle to: that is an imperative mood; a combination of an infinitive of a notional verb without the particle to with modal verbs must, should, can, may, will, would; the Future Indefinite Active Tense - a combination of auxiliary verbs shall and will with an infinitive of a verb of action without the particle to; this is followed by the Present Indefinite Active notional verbs ending in -s; the Past Indefinite Active - notional verbs ending in -ed (for regular verbs; here appears a notion of irregular verbs); the Future Indefinite Active in the Past - a combination of the auxiliary verbs should, would with the infinitive of a verb of action without the particle to.

We have already found out (see the Table), that more complex forms of a predicate are a combination of the verbs to be and to have with Participles I and II. So the next stage is Participle $\boldsymbol{I}$ - an infinitive of a verb with the ending -ing. A combination of the verb to be with Participle I of a notional verb gives the Continuous Active. Further we pass to Participle II - the third form of a verb. A combination of the verb to be with Participle II of a notional verb gives the Indefinite Passive. A combination of the verb to be with Participle I of the verb to be (being) + Participle II of a notional verb gives the Continuous Passive. At this stage combinations of the verb to be with participles (see the Table) come to an end. Further there are combinations of the verb to have with the same participles. A combination of the verb to have with Participle II of a notional verb gives the Perfect Active. A combination of the verb to have with Participle II of the verb to be (been) + Participle I of a notional verb gives the Perfect Continuous. A combination of the verb to have with Participle II of the verb to be (been) + Participle II of a notional verb gives the Perfect Passive. The Future Tense in general is a combination of auxiliary verbs shall and will with an infinitive of a corresponding tense-aspectual form. The Future in the Past is a combination of auxiliary verbs should and would with an infinitive of a corresponding tense-aspectual form. It is in the system of the tense-aspectual forms of the English verb that the logic of English grammar is most evident.

As we can see the English verb tenseaspectual forms may include from one to four different verb forms. It means that a predicate can be formed by:

a) one verb, that may have the ending $-\boldsymbol{s}$ in the Present Indefinite Active Tense and the 
A predicate

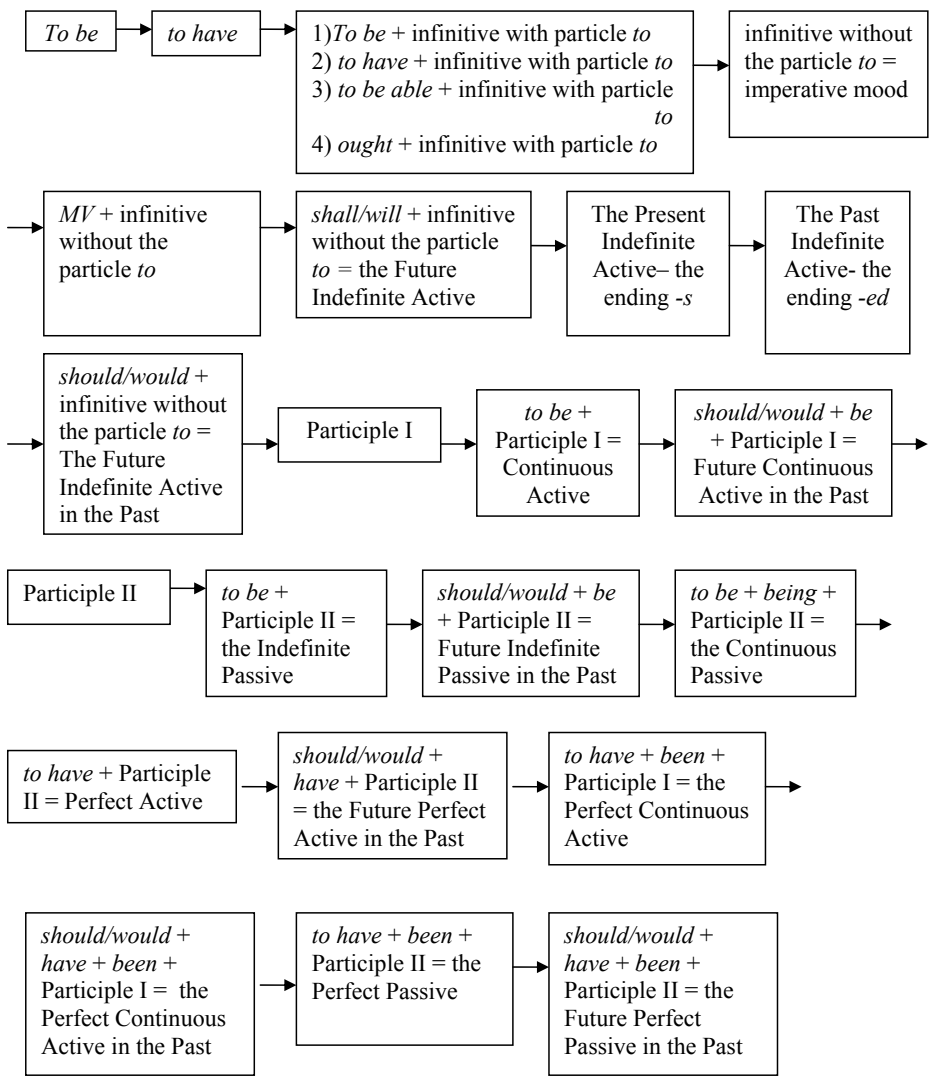

Fig.

ending - ed in the Past Indefinite Active Tense (the Past Tense of irregular verbs must be memorized);

b) two verbs: the Future Indefinite Active Tense, the Future Indefinite Active in the Past Tense, the Present and Past Continuous Active Tenses, the Present and Past Perfect Active Tenses, the Present and Past Indefinite Passive Tenses;

c) three verbs: the Future Continuous Active and the Future Continuous Active in the Past Tenses, the Future Perfect Active and the Future Perfect Active in the Past Tenses, the Future Indefinite Passive and the Future Indefinite Passive in the Past Tenses, the Present and Past Perfect Continuous Active Tenses, the Present and Past Continuous Passive Tenses, the Present and Past Perfect Passive Tenses; d) four verbs: the Future Perfect Continuous Active and the Future Perfect Continuous Active in the Past Tenses, the Future Perfect Passive and the Future Perfect Passive in the Past Tenses.

Besides all the tense-aspectual forms of a verb in the infinitive may be combined with the modal verbs and in this case the number of the verbs in a predicate may also reach four.

The revealed consecution of complication of the English predicate has an objective nature and has all the signs of a law. In other words it is «the Principle of inherent development (complication) of the English predicate».

\section{Discussion}

This is proved by the following event. At the lesson in the Technical University the teacher only gave the formula of the Continuous Passive 
when the lights were suddenly switched off. The teacher decided that it was too dark to go on with the written work and he continued the lesson with the oral work. At the end of the lesson one of the students came up to the teacher and asked to check if he had written and translated in the correct way all the tense-aspectual forms of the Continuous Passive. To the teacher's surprise the student made no mistakes except that he didn't know that the Future and Future in the Past Continuous Passive Tenses couldn't be used.

\section{Conclusion}

My practice of teaching English in this way showed that this technique raises the students' level of understanding of English texts, the quality of their translation and their ability to construct their own English sentences in correct way.

This technique of teaching English may be used at school, at higher school (Institutes and Universities not specializing in the English language), at the faculties of the English language for studying English grammar.

\title{
References
}

Bonk, N. A., Kotiy, G. A., Lukianova, N. A. Uchebnik angliiskogo iazyka. [Textbook on the English language]. Moscow, Vysshaya Shkola. 1982, vol.1 - 640 p., vol. 2 - 604 p.

Kuriaeva, R. I. The optimum way of teaching English. Lambert Academic Publishing, 2014, $69 \mathrm{p}$.

Raymond Murphy. Essential grammar in use with answers. A self-study reference and study book for elementary students of English. Cambridge University press, 1994, 259 p.

Siniavskaia, E. V., Tynkova, O. I. \& Ulanovskaia E. S. Uchebnik angliiskogo iazyka [Textbook on the English language]. Moscow, Vysshaya Shkola, 1982, 264 p.

\section{Закономерность внутреннего усложнения английского сказуемого}

\author{
Казанский наичональный исследовательский технологический университет \\ Россия, 420015, Казань, ул. Карла Маркса, 68
}

\begin{abstract}
Существует огромное разнообразие учебников английского языка. Последовательность преподавания английского языка в них разная. Студенты часто зазубривают сведения по английскому языку, не понимая их. Основой любого языка является его грамматика. Основой английской грамматики является сказуемое. Анализ строения английского сказуемого позволил выявить его внутреннюю логичность, которая имеет характер закономерности. Эта логичность описана с помощью таблиць и уравнений. Оптимальная последовательность изучения английского сказуемого дана в виде схемы. Закономерность усложнения английского сказуемого позволила разработать оптимальную последовательность изучения английского языка. Благодаря этому изучение английского языка становится понятным и, соответственно, более лёгким и коротким.
\end{abstract}

Ключевые слова: английский язык, английская грамматика, английское сказуемое, видовременные формы английского сказуемого.

Научная специальность: 13.00.00 - педагогические науки, 10.00.00 - филологические науки. 